\title{
Hipermodernistyczna, ambiwalentna postawa filozofa
}

\author{
Iwona Lorenc \\ (Uniwersytet Warszawski, Instytut Filozofii)
}

\section{Wprowadzenie}

W przedmowie do 3. wydania książki Wolfganga Welscha Nasza postmodernistyczna moderna znajdujemy cenne spostrzeżenie, które uczynię punktem wyjścia niniejszego szkicu. Jego zadaniem będzie osadzenie postawy określanej mianem hipermodernistycznej nie tylko w kontekście problemów późnej moderny, lecz także w szerszym kontekście niezbywalnej ambiwalencji wpisanej w samą kondycję filozofowania. Ambiwalencja ta jest nie tylko przez filozoficzną, późnonowoczesną refleksję podtrzymywana, ale i w związku z licznymi, radykalnymi zmianami w polu współczesnego doświadczenia, wzmacniana. Niemiecki filozof pisze:

Sugestia epoki (czyli teza, że „postmodernę należy uważać za odrębną, nową epokę, która po prostu pozostawiła za sobą modernę i wszystko robi inaczej) jest tylko najbardziej trywialnym niezrozumieniem postmoderny. Naprawdę bowiem chodziło o przepracowanie i przemianę moderny, której pewne cechy zostały odrzucone, inne jednak zachowane i kontynuowane. Po drugie [...] pewnego (może już bliskiego) dnia wyrażenie „postmoderna” nie będzie już potrzebne, aby odtąd mówić rzeczywiście o jej treściach...”" (podkr. I.L.)

W. Welsch, Nasza postmodernistyczna moderna, przeł. R. Kubicki, A. Zeidler-Janiszewska, Oficyna Naukowa, Warszawa 1998, s. XXIX. 
Jeśli zgodzić się na określenie mianem hipermodernizmu pewnej postawy i ma to być „sposób odnoszenia się do rzeczywistości”, „rozumienie siebie”, "pewna kultura”, „stan ducha części żyjących obecnie ludzi lub pewna propozycja czy też program do zrealizowania” ${ }^{\mathrm{i}}$ jeśli zgodzić się zarazem, że jest to postawa selektywnej akceptacji określonych punktów modernistycznego projektu, akceptacji mimo ich słabości, wykazanych przez postmodernistyczne krytyki, to postawa ta jest dość bliska temu, co prorokuje wyżej cytowana wypowiedź Wolfganga Welscha. Oznacza ona angażowanie się w wybrane elementy projektu modernistycznego z pewnym do nich dystansem. Żyjemy w epoce, w której - wieści Welsch - postmodernizm nie jest nam już (ani jako epoka, ani jako pojęcie) potrzebny, ale korzystamy z wyników jego dekonstrukcyjnej pracy sytuując się ponad postmodernistycznymi dyskursami, utrzymując we wzajemnym napięciu dwie postawy: dystansu krytycznego i emancypacyjnego zaangażowania.

Nie charakteryzuję tutaj możliwych sposobów rozumienia hipermodernizmu, znakomicie uczynił to, np. przywoływany autor. Ważny jest dla mnie istotny, wydobyty przez niego motyw: „Łączy on świadomość odpodmiotowienia z jednoczesną walką o podmiot, a wyrzeczenie się obłędu postępu, prawdy i własnej racji - $\mathrm{z}$ wiarą $\mathrm{w}$ sens działania, ulepszania, otwierania się na prawdę" ${ }^{3}$. Tak rozumiany hipermodernizm miałby być odpowiedzią na potrzebę podtrzymania wiary w sens działań zmierzających do poprawy świata pomimo erozji przekonań i wyczerpania znaczeń pojęć, które składały się na projekt modernistyczny.

\section{Ambiwalentna postawa filozofa}

Wyłonienie się takiej ambiwalentnej postawy, jej osadzenie w postpostmodernistycznym przesileniu oraz jej filozoficzne znaczenie werbalizował już w latach 90. ubiegłego wieku Stefan Morawski. Nigdzie nie pada u niego termin „hipermodernizm”. Znajdujemy natomiast znakomite powiązanie ogólnie pojętej kondycji filozofowania $\mathrm{z}$ sytuacją filozofa poddanego próbie późnomodernistycznego i postmodernistycznego sceptycyzmu. Warto przywołać te wciąż aktualne poglądy choćby po to, aby uzmysłowić sobie, jak bardzo uniwersalny filozoficznie charakter mają wspomniane wyżej hipermodernistyczne ambiwalencje.

Por. M. Trepczyński, Człowiek hipermodernizmu, „Edukacja Filozoficzna” 2013, nr 56, s. 177, 182.

Tamże, s. 178. 
W rozmowie z Anną Zeidler-Janiszewską i Andrzejem Szahajem filozof mówi:

Egzystencja nasza ma w sobie coś tragicznego m.in. dlatego, że stawiamy pytania fundamentalne, na które nie ma jednoznacznych odpowiedzi, że chcemy wiedzy całkowicie niezawodnej, a takiej niepodobna osiągnąć, że szukamy spokoju niezamąconego poprzez zanurzenie się w żywiole boskości, ale spokój ten - niedostępny - jest co najwyżej ułudą ${ }^{4}$.

Skłonność do określania fundamentów (taki sens przypiszemy tu słowom „pytania fundamentalne”) jest więc wpisana w ludzkie dążenie do mądrości, jest elementem dynamicznej wizji wiecznie poszukującej kondycji człowieka. Poszukiwanie to jest dialektyczną grą jawności i pozoru, filozoficznego „fundamentalizmu" i jego krytyki, samoznoszącym się ruchem podważania własnej pozycji filozoficznej; paradoksem zaś tego ruchu jest fakt, iż jest on $\mathrm{w}$ istocie potwierdzeniem pozycji, którą chciałoby się opuścić.

Myśl taką odnajduję w krytycznym ujęciu przez Stefana Morawskiego wielu współczesnych krytyków moderny (m.in. Rorty’ego), gdzie „bumerangiem - jak pisze - wracają odrzucane przez nich pytania, na innym piętrze i inaczej formułowane, wpisując ich jednak w krytykowane przez nich konteksty pytań i odpowiedzi. Odnajduję tu u Morawskiego tego samego ducha przewrotnej krytyki, co np. u Habermasa w jego Filozoficznym dyskursie nowoczesności. Ów duch przewrotnej krytyki towarzyszy zresztą filozofii od zawsze (a przynajmniej od Platona) w sposób podskórny, a odkrywany jest przez próby rekontekstualizacji i reinterpretacji tradycji filozoficznej.

Pozycja filozofa, który wprawdzie dysponuje perspektywą ogólności, chciałby uniwersalizować i totalizować, ale równocześnie ma świadomość konieczności zajmowania określonego miejsca w świecie i nieuniknionego przypisania do tego, co partykularne, nie jest pozycją „między” w znaczeniu „trzeciego środka” lub mechanizmów zapośredniczania. Jest pozycją różnicy w znaczeniu braku jakiegokolwiek przypisania, jest świadomością braku miejsca, „bezmiejscem”, rodzajem bezdomności. Sam filozof do niczego się nie przypisuje, z niczym w pełni nie utożsamia. Jeśli przywołać Heideggerowską ambiwalencję, bardziej przypomina on nomadę, niż stałego mieszkańca domostwa prawdy.

O filozofowaniu, perypetiach dzisiejszej kultury i rebus publicis. Z profesorem Stefanem Morawskim rozmawiają Andrzej Szahaj, Anna Zeidler-Janiszewska, Toruń 1995, s. 10. 
„Prawda” takiego „wędrującego” filozofa nie zatrzymuje się przy żadnym obrazie-micie, który bardziej, niż inne nadawałby się do przytrzymania i odsłonięcia. Jest prawdą niewystarczalności każdego z obrazów-mitów, ich przejściowości i konieczności przekroczenia. Prawda tego, co „między” jest dynamiczna; jest ruchem negacji i podważania złudzeń o adekwacji i pełni. W tej perspektywie wszelkie zaangażowanie człowieka $\mathrm{w}$ świat, będący światem przedstawień, musi się kończyć klęską. Jest zaangażowaniem tragicznym. Tragiczne jest zawierzenie mythosowi, tragiczna jest wiara w logos, gdyż w zderzeniu z mythosem, ukazuje on świadomości krytycznego filozofa swój rewers: drugą stroną logosu jest mit. Kolejne, filozoficzne prawdy to jedynie prawdopodobne mity-obrazy.

Podobnej dwuznaczności własnej filozoficznej pozycji jest świadom - jeśli dobrze odczytuję jego intencje - Stefan Morawski, mówiący o tragizmie filozofowania. Filozofowanie jest czynnością tragiczną: zarazem logocentryczną i mitotwórczą - powiada. W tym głębokim znaczeniu tragiczności, że - jako filozofia metakrytyczna - jest ono świadome własnej aporetyczności: zarazem konieczności i niemożności pełnego zaangażowania się w prawdę. „Pytanie o telos jest - według niego - filozoficznie prawomocne. Myślenia utopijnego nie można człowiekowi odebrać, filozofia musi wciąż odpowiadać na to wyzwanie"s.

Jeśli można mówić o jakimś „,miejscu” tego filozofowania, to - jak w przypadku Platońskiej chory - jest to raczej miejsce słuchania głosów innych, przyzwolenia na te głosy oraz świadomości własnego braku przypisania, czyli „,bezmiejsce” metakrytycznego filozofa, który - niczym Platoński Sokrates - nie dysponuje w stosunku do rozmówców żadną „nadwyżką świadomości”, żadną uformowaną z góry teorią, żadną odkrytą czy objawioną prawdą, nie sytuuje się w roli kapłana tej prawdy.

Zarazem jednak pozwala on zaistnieć każdej prawdzie; dzięki odniesieniu do dyrektywy ogólności i uniwersalności przerastającej partykularyzm poszczególnych prawd, zostają one $\mathrm{w}$ polu metakrytycznej filozofii podniesione do rangi ludzkich sposobów uniwersalizowania i totalizowania. To „miejsce” filozofowania przeobraża prawdopodobny mit w narzędzie logosu. Każdą zaś próbę określenia logosu w postaci jedynej prawdy pozwala zobaczyć jako mit.

Nie ma zatem wykluczania się pomiędzy metakrytycyzmem i postawą aksjologicznego zaangażowania. Obie postawy towarzyszą filozofowaniu, jakie chciałby widzieć i uprawiać Stefan Morawski, co wcale nie znaczy, że jego zdaniem, to ich współtowarzyszenie czyni filozofowanie łatwiejszym. Wręcz

\footnotetext{
O filozofowaniu, perypetiach dzisiejszej kultury..., dz. cyt., s. 11.
} 
odwrotnie: stanowi o dramatyzmie bezustannego wysiłku utrzymania dwóch niemożliwych do pogodzenia nastawień: teoretycznego dystansu i praktycznego współuczestnictwa w konstruowaniu określonej wizji świata.

Metakrytyczna świadomość ma jednak tę przewagę nad „tematyczną” świadomością filozoficzną, która opowiada się za jakąś konkretną, tą a nie inną prawdą, że dostrzega, iż nie jest to prawda jedyna, a wiara w jej osiągnięcie jest iluzoryczna. W przywoływanej już rozmowie Morawski powiada: „Według mego rozeznania, szczególny dramatyzm filozofowania polega - powtórzę - na tym, że musi ono szkicować wizję świata parareligijną, a zarazem wie, że jest to nieosiągalne, oraz że takich wizji (konkurencyjnych) jest bardzo wiele"6.

W Niewdzięcznym rysowaniu mapy autor opowiada się za taką filozofią, która świadoma jest swego posłannictwa, a jest nim stawienie oporu współczesnemu rozchwianiu aksjologicznemu. Jest zatem ta filozofia obroną jakiejś zasady i to nie zasady abstrakcyjnej, spekukulatywnej czy ideologicznej, ale zasady zakorzenionej empirycznie w ludzkich egzystencjalnych doświadczeniach (Morawski określa ją jako „protezę egzystencjalną”). Fundamentem tak widzianej filozofii jest zatem interpretacja owych doświadczeń: „hermeneutyka pierwotna zawarta w doksa” i pozostawałaby ona w związku ze sferą mityczności przysługującą tej sferze.

Morawski stara się więc łączyć w swym projekcie filozofowania (projekcie będącym pewną odmianą hermeneutyki) empiryczne ugruntowanie w określonej historycznie wspólnocie poglądów, będących przedmiotem jego rozumiejącej interpretacji, z metakrytycznym dystansem i interpretacyjnym sceptycyzmem. Tym samym znajduje dla siebie jako filozofa miejsce ambiwalentne i trudne do utrzymania: zarazem „wewnątrz" przestrzeni interpretacyjnej i poza nią.

\section{Modernistyczny kontekst hipermodernistycznej ambiwalencji ${ }^{7}$}

Stanowisko Morawskiego nadaje szerszy, uniwersalny kontekst powyższej ambiwalencji. Z drugiej jednak strony, jak na to wskazuje jego Niewdzięczne rysowanie mapy, lokuje ją w bardzo konkretnej, historycznie określonej sytuacji. Jest ona naszym udziałem, charakteryzuje pewien stan ducha kultury aktual-

Jw., s. 19.

Część niniejszego podrozdziału powtarza sformułowania zawarte we wprowadzeniu redagowanej przeze mnie monografii zbiorowej Między integracją a rozproszeniem. Doświadczenie estetyczne nowoczesności, która jest aktualnie wydawana przez Wydawnictwa Uniwersytetu Warszawskiego. 
nej, późnej nowoczesności, która postmodernizm w pewnym sensie ma już za sobą. Wydaje się, że na tym, przepowiedzianym przez Welscha etapie właśnie się znajdujemy. Dyskusje wokół projektowanych dziś pojęć służących intelektualnemu zagospodarowaniu owego stanu świadomości wyczerpania się postmodernistycznych paradygmatów, a wśród nich umieszczam pojęcie hipermodernizmu, skłaniają nas do ponownego spojrzenia na modernę ${ }^{8}$ Przyjrzenia się jej w sposób bogatszy o rezultaty jej postmodernistycznych dekonstrukcji i różnorakich kosztów, głównie aksjologicznych, którymi są one obciążone. Nie chodzi o to, aby wrócić do niedokończonego projektu oświecenia w jego wymarzonej przez nowoczesność postaci. Być może zresztą jest tak, że nie tylko projekt ten nie doczekał się realizacji, ale też jako projekt nie zaistniał w czystej, pozbawionej wątpliwości i wewnętrznych pęknięć postaci.

Nawiązując do tezy Latoura, możemy dopuścić myśl, że „nigdy nie byliśmy nowocześni”. Nowoczesność jako wciąż realizowany i niedający się zrealizować projekt, od renesansu erodowana jest przez jej własne sprzeczności i wyrastające z nich krytyki. Nigdy nie istniała poza własną autodestrukcją. Antymodernistyczne (przede wszystkim postmodernistyczne) filipiki to przedwcześnie oznajmiony koniec pewnego złudzenia o możliwości urzeczywistnienia projektu moderny oraz radykalizacja jego wymiaru autokrytycznego.

Gest przekraczania, zrywania z tradycją wpisany jest wszak w najgłębszą rację bytu epoki, która samą siebie określa mianem nowoczesnej. Praktyki przekraczania granic i autonegacji wpisane są w nowoczesność. Habermas w tekście Modernizm - niedokończony projekt pisze, że:

Modernitas, [to] słowo o zmiennej treści, wyraża zawsze świadomość epoki, która ustosunkowuje się do starożytnej przeszłości, aby samej móc pojmować się jako rezultat przejścia od starego do nowego. Dotyczy to nie tylko renesansu, od którego dla nas rozpoczyna się nowożytność [...]. Za nowoczesne uchodzi zatem to, w czym może się obiektywnie wypowiedzieć spontanicznie się odnawiająca aktualność ducha czasów9

8 Termin „nowoczesność” rozumiem szeroko, tak jak czyni to Wolfgang Welsch w Naszej postmodernistycznej modernie. Wydobyte przez tłumaczy polskiego wydania książki we wstępie do niego niuanse znaczeniowe wpisane w różnicę między terminami „nowoczesność” i „moderna” umożliwiają dość swobodne, niekiedy zamienne operowanie tymi terminami. Postmoderna zaś jest przeze mnie - za Welschem - traktowana jako autorefleksyjna faza moderny.

9 J. Habermas, Modernizm - niedokończony projekt, przeł. M. Łukasiewicz, w: Postmodernizm. Antologia przekladów, red. R. Nycz, Wydawnictwo Baran i Suszczyński, Kraków 1998, s. 30. 
Samo pojęcie odnawiającej się aktualności ducha czasów zakłada mechanizm antagonizowania, wyłaniania sprzeczności.

Programy holistyczne, dążenie do jednorodnego obrazu świata (jako projektu tego, co nowe) współistnieje w nowoczesności z jej tendencjami do rozproszenia i różnicowania. Wolfgang Welsch tak określa ten ostatni aspekt:

Nowoczesność jest [...] epoką rozbicia i rozproszenia. To ona obdarzyła nas oświeceniem, bezbożnictwem, humanizmem, liberalizmem i indywidualizmem. Są to zaś [...] zjawiska jednoznacznie samodestrukcyjne i dlatego moderna stała się także epoką postępującej dezintegracji społecznej, kulturowej i psychicznej ${ }^{10}$.

Dlatego też można powiedzieć, że nowoczesność nigdy nie istniała poza własną autodestrukcją. Za sprawą ruchów opozycyjnych w obrębie moderny

dochodzi do częściowych rewizji lub rozszerzeń, czyli w sumie do dynamizacji pierwotnego programu. Rousseau nie tylko przeciwstawia się Oświeceniu, stanowi zarazem już jego część ${ }^{11}$.

Autokrytycyzm ten związany jest z modernistycznym indywidualizmem (od Kartezjusza po Husserla) i konstrukcją samorozumiejącej się podmiotowości. Ma wymiar świadomościowy, kulminuje w filozoficznej świadomości toczącej grę o prawdę.

Późna moderna przesuwa akcenty, poszerza przestrzeń krytycznej autorefleksji o przejawy społeczno-kulturowego, cywilizacyjno-ekonomicznego funkcjonowania człowieka, o to, co nieświadome. Późna moderna, tym bardziej postmodernizm wieści kres podmiotu. Nie jest on - jak się okazuje - ostateczny. Trwa, choć domaga się nowych formuł i nowych kontekstów.

Warto w tym miejscu przywołać optymistyczną nadzieję Scotta Lasha, który w Modernizacji refleksyjnej zauważa, ze wprawdzie napór zmian w obrębie struktur społecznych blokuje dalszy rozwój podmiotowości zakładanej przez modernizm, ale zarazem zastępujące je strukturami informacyjnymi i komunikacyjnymi stwarzającymi warunki dla nowego, zredefiniowanego podmiotu (świadomego i wolnego w nowych znaczeniach tych terminów). Lash słusznie podkreśla, że w obrębie moderny dochodzi do swoistego rozdwojenia, do

10 W. Welsch, Nasza postmodernistyczna moderna, dz. cyt., s. 82.

11 Tamże, s. 104. 
wyłonienia się jej drugiej postaci: rozum i modernizacja zwracają się bowiem przeciwko sobie; system tworzony przez modernizację prze do zniszczenia „świata życia”. W rezultacie:

Oświecenie lub modernizacja w erze zorganizowanego kapitalizmu staje się własnym, budzącym niepokój sobowtórem, kiedy sfera publiczna otwarta przez wymianę rynkową, zamieniła się w hierarchicznie zorganizowane, monopolistyczne przedsiębiorstwo kapitalistyczne; kiedy demokratyczny indywidualizm w życiu politycznym zamienia się w mechaniczną anonimowość legalno-racjonalnej biurokracji, kiedy twórczy zapał awangardy estetycznej zamienia się $\mathrm{w}$ przypominające więzienia wieżowce i osiedla mieszkaniowe $\mathrm{z}$ lat 60-tych XX wieku ${ }^{12}$.

W przeciwieństwie do wewnętrznie autodestrukcyjnej, choć dążącej do scalania modernizacji prostej, rysowany przez Lasha projekt modernizacji refleksyjnej opisuje mechanizmy „nieuporządkowanego rozpadu na połączone w sieci okręgi małych, relatywnie autonomicznych przedsięwzięć"13. Odpowiadają temu opisowi Lasha strategie nowoczesności i „naszej ponowoczesnej nowoczesności” opisywane przez Welscha czy Jean-François Lyotarda (od obrazów dialektycznych Waltera Benjamina, mikrologii Adorna po Lyotardowskie mikronarracje). W efekcie nie ma jednej moderny, wyłania ona swego sobowtóra, a w konsekwencji - rozpada się na wiele centrów.

Z podwójnego obrazu moderny - monistycznej i zarazem pluralistycznej wyrasta podwójny obraz postmoderny. Nie przestaje on pełnić funkcji matrycy również dla nowych, mniej lub bardziej efemerycznych prób dystansowania się wobec postmodernizmu (posthumanizmu, nowych wersji filozoficznego femininizmu, hipermodernizmu itp). Dziedziczą one ową matrycę w postaci pluralizmu nacechowanego emancypacyjnie i etycznie. Poruszają się już nie w nowoczesnym, pooświeceniowym paradygmacie wolności od przyrody, ale w kategoriach emancypacji tego, co przyrodnicze w nas i poza nami. W posthumanizmie w jego feministycznej odsłonie nie chodzi już - jak w modelu oświeceniowym - o przezwyciężanie przemocy ze strony przyrody poprzez doskonalenie form panowania nad nią i wynoszenia jej ku temu, co ludzkie, ale o re-definiowanie

12 S. Lash, Modernizacja refleksyjna. Polityka, tradycja i estetyka w porzadku społecznym nowoczesności. Polityka, tradycja i estetyka w porządku społecznym nowoczesności, przeł. J. Konieczny, Wydawnictwo Naukowe PWN, Warszawa 2009, s. 148.

13 Tamże, s. 149. 
tego, co ludzkie na poziomie krytycznego, świadomego uczestnictwa w tym, co przyrodnicze, o bycie elementem przyrody.

Jeśli można użyć wobec tej tendencji określenia „naturalizm”, to byłby to naturalizm refleksyjny, krytyczny. Oczywiście założyć należy nowy sens owego krytycyzmu: byłby on już nie tyle aktem podmiotowego, świadomościowego samooglądu, ile symptomem autodestrukcji cechującej aktualny stan nowoczesności. Byłby to autorefleksyjny krytycyzm partycypacji i zanurzenia w doświadczeniu nowoczesnym $w$ przeciwieństwie do modernistycznego (wzgl. nowożytnego) wzorca krytycznego dystansu. Przykładów dostarczają choćby humanistyczny feminizm (Rosi Braidotti, Donna Haraway), który według określeń Braidotti:

wprowadził materializm nowego typu - materializm ucieleśniony i zakorzeniony; przesłanką jest tu „materialistyczna koncepcja ucieleśnienia” z jednej strony znajdująca filozoficznego sojusznika w licznych wersjach postfenomenologii, z drugiej zaś - sprzymierzona z filozoficzną i polityczną krytyką władzy (jako maskulinistycznego uniwersalizmu) ${ }^{14}$.

Jak z kolei pisze Haraway:

krytycyzm ten jest zanurzony, usytuowany, gdyż to podporządkowani, nie zaś uprzywilejowani, mają większą szansę dostrzec i zakwestionować prawa rządzące danym systemem ${ }^{15}$.

\section{Ku nowym konceptualizacjom ambiwalencji dystansu i zaangażowania: wybrane praktyki przekraczania modernistyczno-postmodernistycznej opozycji}

Bezinteresowny dystans, który cechował doświadczenie estetyczne w estetyce pokantowskiej coraz częściej zastępowany jest postawami zaangażowania i partycypacji. Cechują one nie tylko praktyki artystów, począwszy od awangardy, łamiących bariery między życiem i sztuką, nie tylko odbiorców, którzy stając

\footnotetext{
14 R. Braidotti, Po czlowieku, przeł. J. Bednarek, A. Kowalczyk, przedm. J. Bednarek,Wydawnictwo naukowe PWN, Warszawa 2014, s. 74.

15 D, Haraway, Wiedze usytuowane, cyt za: R. Braidotti, Po człowieku, dz. cyt., s. 74.
} 
się współtwórcami sztuki, kreują nowe formy życia, ale i samych teoretyków. Partycypacyjny i zaangażowany charakter nowych teorii sztuki, do których należą omawiane koncepcje, polega na włączaniu się refleksji estetycznej w opisywany proces autokreacji: wprowadzając do praktyk artystycznych element autorefleksji, przyczynia się ona do wyłaniania się nowych form życia, alternatywnych wobec tego, co zastane.

Zdaniem Michela Maffesolego dzisiejsza kultura to „maszyna do wytwarzania bogów", jak określa ją za Bergsonem w Le réenchantement du monde, maszyna, której materią są zbiorowe mity i archetypy, zbiorowe ekspresje uczuć: od miejskich form teatralizacji życia po internet wciela ona w życie to, co ponadosobowe, kolektywne. Współczesna muzyka, teatr, sport turystyka są formami manifestowania się sił ukrytych przed indywidualną świadomością podmiotu, wymykających się formule twórczości podmiotowej. Współcześnie - zauważa Maffesoli wpisujący się tym samym w żywą dyskusję na temat postnowoczesnego podmiotu, gdzie sytuowałby się, jak przypuszczam, blisko koncepcji podmiotu transwersalnego Welscha - jesteśmy świadkami przeobrażania się tradycyjnej formuły jednostkowego podmiotu w „personę”, na którą składa się wielość ról społecznych, „masek” i sposobów wizualizowania tego, co przed indywidualną świadomością ukryte, a co jest swoistym wehikułem treści kolektywnych.

Późnonowoczesna, zmedializowana kultura umożliwia nowe formy uniwersalizacji życia zbiorowego, wymusza nową formułę podmiotu, zaciera granice wyznaczane przez nowoczesny indywidualizm. Zarazem wypracowuje ona postawę gotowości przyjmowania rozmaitych wersji przeżywanych światów, nie pozwalając na dłużej przywiązać się do żadnego z nich. Stale pozbawia złudzeń i oczekiwań co do stabilności którejś z tych wersji.

Estetyka partycypacji (Maffesoli, Nicolas Bourriaud) redefiniuje nowoczesne doświadczenie dokonując istotnych przesunięć kategorialnych w stosunku do kategorii kluczowych dla pokantowskiej estetyki autonomicznej. Przesunięcia te rysują się przede wszystkim w polu napięć między kategoriami dystansu i zaangażowania i prowadzą do nowego sposobu definiowania podmiotu artystycznej kreacji. Nie ma on charakteru jednostkowego, intencjonalnego, ani tym bardziej nie podlega charakterystyce substancjalizującej. Siłą tworzącą jest samoartykułujące się życie społeczne, ogniskowane w ludzkich praktykach (m.in. w praktyce artystycznej). Bourriaud i Maffesoli powielają w pewien sposób matrycę dobrze znaną filozofii: poietyczną siłą kreacji obdarzane w niej bywa samo życie (Fryde- 
ryk Nietzsche), Bycie (Martin Heidegger), Byt (późny Maurice Merleau-Ponty), samostwarzajaca się Natura (Mikel Dufrenne) itp. Bourriaud i Maffesoli w swojej koncepcji artystycznej i estetycznej partycypacji mieszczą się w tak ogólnie rozumianym modelu pojetycznym.

Do charakteryzowanych wyżej aktualnych postaw badawczych wobec nowoczesnego doświadczenia, które wyprowadzają nas poza przestrzeń dyskursów postmodernistycznych, ale też pozostają w krytycznej relacji wobec modernistycznej siatki pojęciowej, należy zaliczyć również zwrot performatywny, który wedle jego orędowników miałby wypierać i zastępować wyeksploatowane już nurty: konstruktywizm, poststrukturalizm, dekonstrukcję, tekstualizm, narratywizm. Lepiej niż one dogania on bowiem zmiany w świecie, lepiej odpowiada nowym wyzwaniom humanistyki ze strony zmieniającego się świata.

$\mathrm{Na}$ osłabienie podmiotu $\mathrm{w}$ wymienionych nurtach zwrot performatywny reaguje umocnieniem zredefiniowanej podmiotowości, często hybrydalnej, niekiedy wręcz nieludzkiej. Kontemplacja zostaje zastąpiona zmianą, co czyni dyskurs zwrotu performatywnego podatnym na liczne polityczne aplikacje. Praktyki performerskie pełnią powyższe funkcję na różnych, niekiedy bardzo nikłych piętrach refleksyjnej samoświadomości. Na przykład, teatr rozpatrywany w kategoriach działalności performatywnej bardziej niż inne formy tej działalności kryje w sobie ogromny potencjał autorefleksyjny. Wskazuje na własny, przedstawieniowy charakter, a poprzez tę refleksyjną autodemonstratywność obnaża przedstawieniowy charakter kulturowego, społecznego i politycznego środowiska człowieka nowoczesności. Obnaża - mówiąc językiem Heideggera - mechanizmy „światoobrazu” i w tej swojej demaskatorskiej funkcji zbliża się do filozofii krytycznej, której patronują Nietzsche i Heidegger. Tacy autorzy jak Janelle Reinelt czy Joseph Roach piszą o filozofii krytycznej, że w tym sensie ma ona charakter performatywny, że poddaje ona rewizji zastane sensy, na nowo je formułuje, kwestionuje je, rzuca im wyzwanie i czasami je potępia ${ }^{16}$. Traktowane performatywnie teatr i filozofia funkcjonalnie zbliżają się do siebie. Burząc zastane paradygmaty, dotykając granic przedstawialności, wykraczając poza ustalone znaczenia i normy znaczeniowe, zasługują na miano praktyk liminalnych. Toteż bardzo trafnie Jon McKenzie tak właśnie postrzega ich pokrewieństwo.

16 Por. J. McKenzie, Performuj albo... Od dyscypliny do performansu, przeł. T. Kubikowski, Universitas, Kraków 2011, s. 41. 
Uprzywilejowują one wszelkie stany „pomiędzy”, praktyki przejścia i towarzyszące im strategie oporu i transgresji. Opierają się na pewnej kategorii działań, których „przestrzenne, czasowe i symboliczne „pomiędzy” zawiesza społeczne normy, rzuca im wyzwanie, igra z nimi i może nawet je przemienia ${ }^{17}$. Stąd szczególne eksploatowanie figur obrzeży, marginesów i „radykalnych praktyk” będących nowoczesnymi zastosowaniami rytów przejścia.

Dodajmy do powyżej rysowanego szkicu fascynacje mocami sprawczymi nowych technologii, które zdają się kryć w sobie odziedziczony po modernizmie potencjał nadziei na nowe perspektywy emancypacyjne, obywające się bez metafizycznych obciążeń takimi ważnymi dla nowoczesności kategoriami, jak podmiot, człowiek, tożsamość itp. Nowe formy oporu wobec skutków prostej modernizacji zmuszają wspomnianych zwolenników nowego typu myślenia i działania do swoistego, pragmatycznego mariażu filozofii i praktyki, do - zdaniem Braidotti:

pragmatycznej formy mikropolityki, odzwierciedlającej złożony i nomadyczny charakter współczesnych systemów społecznych i zamieszkujących ją podmiotów ${ }^{18}$.

\section{Podsumowanie}

Zarysowuję powyższy obraz tendencji post-postmodernistycznej humanistyki badającej stan późnonowoczesnego doświadczenia, aby wskazać na aktualny punkt dojścia określonego stanu świadomości teoretycznej, który - wobec wyczerpywania się heurystycznej mocy napięć między nowoczesnością i ponowoczesnością - kieruje ku poszukiwaniu konceptualizacji nowoczesnego doświadczenia poza tą opozycją.

Modernizm i wieńczący to dzieło postmodernizm dokonały rozpoznania utraty przez człowieka bezpieczeństwa ontologicznego, by posłużyć się określeniem Anthony Giddensa. Zdiagnozowały nowoczesne doświadczenie jako postępującą, czasoprzestrzenną dystancjację, jako proces wykorzenienia, mówiąc zaś językiem Heideggerowsko-Vattimowskim - jako postępującą utratę podstaw.

17 Tamże, s. 64.

18 R. Braidotti, Po człowieku, dz. cyt., s. 83. 
Wiarę w podstawy - skutecznie przekonują nas ci filozofowie - mamy już za sobą. Pozostaje nam kroczyć ich słabnącymi śladami (przeboleć fakt, że słabną - zgodnie z logiką Vattimowskiego Verwindung), a przy tym jednak odkrywać, że wciąż jesteśmy przez nie prowadzeni. Wiara w to, że jest się dzisiaj już poza modernizmem byłaby tylko powtórzeniem modernistycznego mitu radykalnego zerwania z przeszłością.

\section{Bibliografia}

Braidotti R., Po człowieku, przeł. J. Bednarek, A. Kowalczyk, przedm. J. Bednarek, Warszawa 2014.

Habermas J., Modernizm - niedokończony projekt, przeł. M. Łukasiewicz, w: Postmodernizm. Antologia przekładów, red. R. Nycz, Kraków 1998.

Lash S., Modernizacja refleksyjna. Polityka, tradycja i estetyka w porzadku społecznym nowoczesności. Polityka, tradycja i estetyka w porządku społecznym nowoczesności, przeł. J. Konieczny, Warszawa 2009.

McKenzie J., Performuj albo... Od dyscypliny do performansu, przeł. T. Kubikowski, Kraków 2011.

O filozofowaniu, perypetiach dzisiejszej kultury i rebus publicis. Z profesorem Stefanem Morawskim rozmawiaja Andrzej Szahaj, Anna Zeidler-Janiszewska, Toruń 1995.

Trepczyński M., Człowiek hipermodernizmu, „Edukacja Filozoficzna” 2013, nr 56, s. 171-184.

Welsch W., Nasza postmodernistyczna moderna, przeł. R. Kubicki, A. Zeidler-Janiszewska, Warszawa 1998.

\section{Streszczenie}

Zadaniem szkicu będzie osadzenie postawy określanej mianem hipermodernistycznej nie tylko w kontekście problemów późnej moderny, ale i w szerszym kontekście niezbywalnej ambiwalencji wpisanej w samą kondycję filozofowa- 
nia. Ambiwalencja ta jest nie tylko przez filozoficzną, późnonowoczesną refleksję podtrzymywana, ale i w związku z licznymi, radykalnymi zmianami w polu współczesnego doświadczenia, wzmacniana. Hipermodernizm miałby być odpowiedzią na potrzebę podtrzymania wiary w sens działań zmierzających do poprawy świata pomimo erozji przekonań i wyczerpania znaczeń pojęć, które składały się na projekt modernistyczny i pomimo wyczerpania się postmodernistycznych paradygmatów. Przedstawiam w tekście wybrane dyskusje wokół projektowanych dziś pojęć służących intelektualnemu zagospodarowaniu owego stanu świadomości.

Słowa kluczowe: moderna, postmodernizm, hipermodernizm, kondycja filozofii, metakrytycyzm

\section{Summary}

\section{Philosopher's Hypermodernist, Ambivalent Attitude}

The aim of this essay is to place the so-called hypermodernist attitude in the context of the problems of late modernity as well as the broader context of the inherent ambivalence intrinsic to the very condition of philosophising. This ambivalence is not only upheld by late modern philosophical thought but also - due to the many radical changes in the field of contemporary experience - enhanced by it. Hypermodernism is supposed to be an answer to the need to uphold the faith that activities aimed at improving the world are not pointless despite the erosion of beliefs and the depletion of meanings of the ideas which comprised the modernist project, and despite the exhaustion of postmodern paradigms. In the text, I present selected discussions around ideas that are currently being developed to intellectually manage this state of awareness.

Keywords: modernism, postmodernism, hypermodernism, condition of philosophy, metacriticism 